\title{
Learning Engagement in Virtual Environment
}

\author{
Subhenur Latif \\ Department of Computer \\ Science and Engineering \\ Daffodil International University
}

\begin{abstract}
Today e-learning is blooming as a vital part of digital age education which facilitates a virtual environment for enhanced interaction \& engagement between teachers and fellow learners and to engage them with resources for effective learning. Despite having significant potential, the Google classroom is still vastly underutilized especially in developing countries e.g. Bangladesh. This study is an endeavor to identify the factors responsible for poor engagement of students in Google classroom and to explore other critical barriers behind the underutilization of this virtual learning platform. From the empirical findings, this study attempts to explain and testify the effectiveness of strategies adopted in different classes for more engagement and proactive participation from the students. The primary data was acquired through a baseline survey which was carried out using a pre-defined structured questionnaire with a sample size of 350 randomly selected undergraduate students from different levels. Several case studies were also carried out along with participatory and non-participatory observations of student activities as methodology of this research. The research questions were: a) Do the peer influence improves student engagement in critical thinking? b) Do the passive role of teacher increase the active participation of students? c) Do the students prefer Facebook groups as a platform for group study instead of Google classroom? The findings of this study, empirically unearths peer influence as a significant determinant of the effectiveness of Google classroom. Furthermore, the majority of learners are found more comfortable while teachers play passive facilitators' role instead of active intervention whereas the availability of Facebook groups as a popular alternate platform for interaction may limit the utilization of Google classroom. Finally the data analysis reveals that the strategic changes in selected dependent variables facilitate more proactive engagement by the learners which in turn enhance the effectiveness through optimum utilization of the opportunities of Google classroom as a virtual platform for more effective learning.
\end{abstract}

\section{General Terms}

E-learning, Virtual Education

\section{Keywords}

Virtual classroom, Facebook group, Learning Engagement, peer influence, critical thinking, ownership

\section{INTRODUCTION}

Virtual classroom is an integral part of e-learning. The study of Martin, F and Parker, M. A. (2014) states that many online courses are offered; at the same time faculties are adopting synchronous virtual classrooms that enable them to interact with students in real time [8].The Virtual classroom, a synchronous form of e-learning has been embraced by many organizations in their attempt to promote workforce learning while trying to cut travel time and costs associated with face to face instructor-led training (Xanthoula, A 2015). In May
2014 Google has announced a new Google app "Google classroom" for educational purpose. Google Classroom is considered as one of the best platforms out there for enhancing teachers' workflow. It provides a set of powerful features that make it an ideal tool to use with students. 'Classroom helps teachers save time, keep classes organized, and improve communication with students. It is available to anyone with Google Apps for Education, a free suite of productivity tools including Gmail, Drive and Docs.'(2015).

At institutions currently signed on with Google, there are several ways in which Google Classroom could be beneficial to both students and faculty.

- Google Classroom has the potential to streamline communication and workflow for students by providing a single access point to discussion threads and assigned work

- Google Classroom can help students to keep their files more organized because all their work can be stored paperless in a single program

- Faculty can more quickly identify which students may be struggling with their assignments due to the tracking mechanisms associated with assigned tasks

- Grading processes can be simplified because of the grading features associated with student submissions

The writer is involved with research on virtual learning for quite a few years and her university was using an online application for this purpose before moving to Google classroom in September, 2014. But in these years of journey, Google classroom has been underutilized in most of the cases. Despite having some attractive and useful features, students are often found reluctant to learn in Google classroom; their participation is alarmingly poor in some cases. The paper finds out what are the factors for poor engagement of students in Google classroom, how the teacher and student use it and how to use the best of it, what works best and its' effectiveness and limitations. A baseline survey and literature review had led to the formation of research questions. The ultimate objective was to search the answers of three research questions:

a) Do the peer influence improves student engagement in critical thinking?

b) Do the passive role of teacher increase the active participation of students?

c) Do the students prefer Facebook groups as a platform for group study instead of Google classroom?

\section{LITERATURE REVIEW}

There have been published a lot of research papers on elearning or online based learning hitherto. Most of the publication was about the effectiveness of Facebook or its effect upon young generation.

When a university of Cape Town was using its own websites 
called VULA for study purpose it was found that, students are more active in Facebook [1]. They said that, Facebook are giving them more flexible environment for sharing and gathering knowledge. And VULA does not connect junior cohorts of learners to their seniors, even when they are students in the same department and have common interests. But Facebook allowed it. They added that VULA is more formal than Facebook.

For e-earning a Facebook group is effective because of its easy interface, understandable features, and it provide interactivity with other users and instructors [2]. Students use Facebook to maintain existing relationships, to meet new people, to make oneself more popular, to pass time, express or present oneself, for learning purposes, as a task management tool, for student activism [3].

Some studies show that the effects of over Facebooking. Students who spend more time in

Facebook their CGPAs is lower than the less active or nonusers. Most of the Student use Facebook as fun not seriously but there are also some negative effect of Facebook use [3, 5]. Social presence is the most important factor that determines students' usage of Facebook. It provides users to share personal info, as well as they can create group event etc., that are really informative. They also connect people with friends and others who work, study, and live around them [4]. Facebook provide an extraordinary capacity to express themselves, establish various relationships, and interact with others at any distance in time and space, addressing their selfexpressive, networking and informational needs. Online social networking not only expands individuals' large-scale networking capacity but also enables individuals to maintain close relationships with a small group of friends [5].

Facebook is different from phones. One can communicate with many people at the same time. In real life, it is difficult to get together with that many people for learning purpose. A big portion of students were neutral about their attitudes toward Facebook use [6]. The findings showed that the time commitment to the course Facebook pages was greater than the time students would spend attending classes per week if enrolled in a four credit course. On the course Facebook pages, the wall contained resources such as videos, document links, and web pages related to course topics [6].

Janzen, M. (2014), points out the some benefits of using Google Classroom. "Google Classroom's design purposefully simplifies the instructional interface and options used for delivering and tracking assignments; communication with the entire course or individuals is also simplified through announcements, email, and push notifications."[10]. It integrates and automates the use of other Google apps, including docs, slides, and spreadsheets, the process of administering document distribution, grading, formative assessment, and feedback is simplified and streamlined(Janzen, M. 2014).

Chehayeb, A. (2015), Google Classroom Software Engineer mentions that they built classroom "to save time". He claims that Google is launching some features like export grades to Google Sheets, easier to update grade point scale ,keyboard navigation for entering grades, sort by name on grading page etc. to save teachers' time [7].

Google Classroom presents more professional and authentic technology to use in learning environment as Google apps represent "a significant portion of cloud-based enterprise communications tools used throughout the professional workforce." (Mary, 2014).
This app is easily accessible and useable to instructors and learners in both face-to-face learning environments and fully online environment. This enables educators to explore and influence "flipped instructional methods more easily as well as automates and organizes the distribution and collection of assignments and communications in multiple instructional milieus." (Mary, 2014)

Google Classroom is designed to be responsive. It is easy to use on any mobile device. "Mobile access to learning materials that are attractive and easy to interact with is critical in today's web connected learning environments."(Janzen, M 2014)

Keeler, A. (2014) also mentions several other benefits of using Google Classroom. She mentions how Google Classroom ensure streamline counseling only by posting an announcement [9]. Crawford, A. R. (2015) states that Google Classroom facilitates collaborative learning. Here teacher can upload materials and can give feedback to students .Students also can upload materials and make personal comment. Moreover, students can collaborate with each other. They can share their documents and assignment and thus they can produce the best assignment. Keeler, A (2014) also states that Google classroom encourage collaboration between students.

\section{METHODOLOGY}

In order to find the answer of the research questions, a baseline survey was conducted to pull out the real picture of using Google classroom from the active users. It was carried out using a pre-defined structured questionnaire with a sample size of 350 randomly selected undergraduate students from different levels. Data were also collected through interviews and observations. The interview followed 'structured' format where detailed one-to one interview of the students were conducted. In total, 64 students from different levels were interviewed. There were interview questions out the facts as well as the attitudes and opinions of students and teachers. This study followed 'Typical Case Sampling' which is a type of purposive sampling, suggested by Wiersma \& Jurs (2005) in their book Research Methods in Education: An Introduction. For each research question, at least one test case had been analyzed [11].

\section{TEST CASES}

\subsection{Test Case-I for RQ1: Do the peer influence improves student engagement in critical thinking? \\ In GC (Google Classroom), the common strategy of} completing written assignments is to analyze and solve a particular problem individually and submit it in due time. In this way, most of the students do nothing but copy-and-paste from their friends and do not learn anything at all although successfully submit the assignment. Therefore, teacher finds it really hard to evaluate. It also refers that it is very much difficult to engage students into critical thinking by following traditional way. There are always some students in a class who play a secondary teacher's role among his or her friends group since he or she understands best in the class. But in virtual environment, how teacher will identify those sincere students? After the rigorous observation of this matter of practice, a new way of task assigning in GC had been introduced. In this method, each student was assigned to solve specific problems and then teach other peers in virtual classroom. Marks were involved in two parts. In first part, student prepares assignment and explains it to others. In second part, student makes queries by commenting in others solutions. 


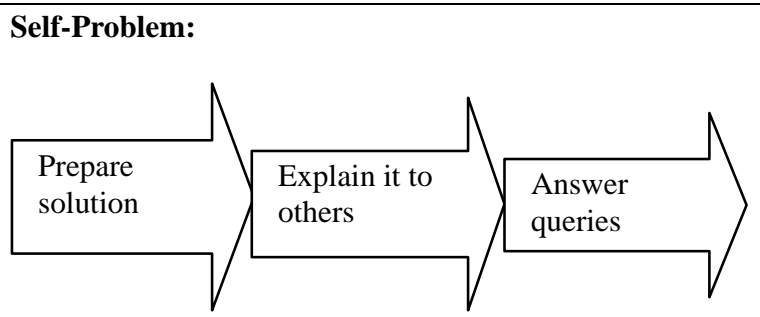

\section{Others' Problem:}

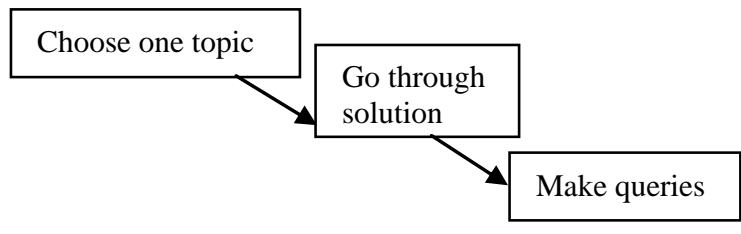

Fig 1: Google Classroom Assignment Designing Process

The response was really high and some of them have made their own video tutorial which is fascinating (Fig. 2).

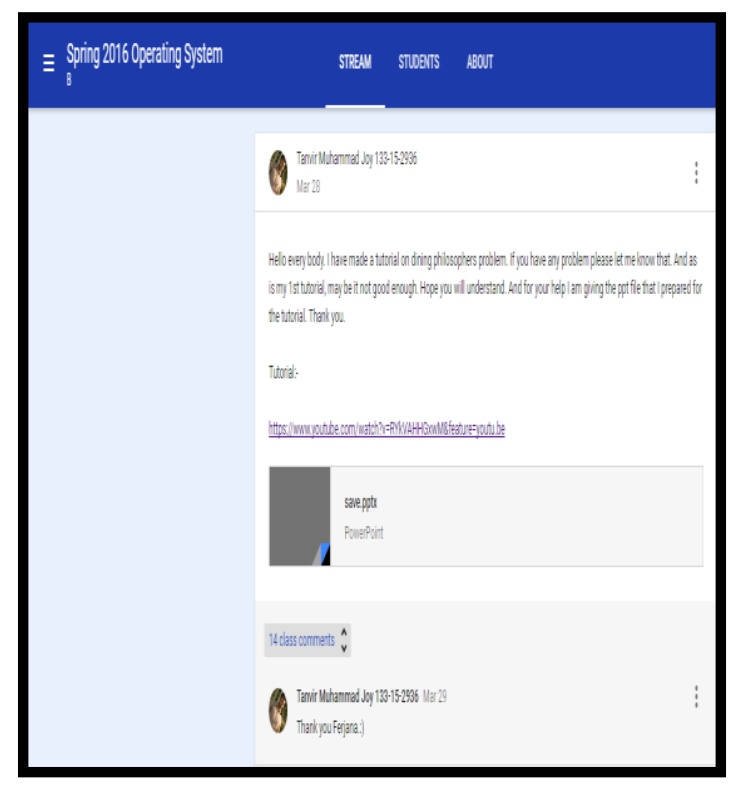

Fig. 2: Student has made own video tutorial

Later on, students were asked about the new experience in face-to-face class discussion. Almost all of them have said that it really make them think and work. A very few exception did not liked it since it requires hard work for getting marks although they have agreed that this method is more effective to learn.

\subsection{Test Case-II for RQ 2: Do the passive role of teacher increase the active participation of students?}

It is not possible to ensure one hundred percent participation of students in a regular classroom which might be achievable in virtual classroom. Here, everybody has own space and time to comment for proactive participation. Besides, internet facility opens the door of massive resources. In order to utilize these opportunities, live class had been arranged in GOOGLE CLASSROOM. The class had been designed differently comparing to regular class. Regular class design comprises of mainly four steps:

\section{Step 1: Formation of Problem (Actor: Teacher) \\ Step 2: Solution of Problem (Actor: Teacher) \\ Step 3: Discussion (Actor: Teacher and student) \\ Step 4: Task Performing (Actor: Student)}

Here teacher plays the active role in majority of steps where response rate from students is alarmingly poor (approximately $20 \%$ ). For some limitations, in this method, all the students do not participate or follow the lecture. Students are found mostly attentive when a task is given to them to perform (in step 4). But, lots of mistakes remain in their performance since one-to-one correction is not possible due to time limitation.

\begin{tabular}{|l|l|}
\hline $\begin{array}{l}\text { Step 1: Formation of } \\
\text { Problem } \\
\text { Actor: Teacher } \\
\text { Deliverable: A } \\
\text { question related with } \\
\text { an idea of study }\end{array}$ & \begin{tabular}{l}
$\mid \begin{array}{l}\text { Step 2: Task } \\
\text { Performing } \\
\text { Actor: Student } \\
\text { Deliverable: Posts } \\
\text { comprising answers } \\
\text { within time limit }\end{array}$ \\
\hline $\begin{array}{l}\text { Step 4: Solution of } \\
\text { Problem } \\
\text { Actor: Teacher and } \\
\text { Student } \\
\text { Deliverable: } \\
\text { Collective Solution }\end{array}$ \\
\hline
\end{tabular} \mid \begin{tabular}{l}
\hline \\
\hline
\end{tabular} \\
\hline
\end{tabular}

Fig. 3: Proposed Design of Live Class in Google Classroom

To reduce these shortcomings, teacher may play the passive role. The writer had taken this sort of live classes where she found handsome rate of response from her students. Firstly, teacher had started the initial talk with a question and pointed out various relevant concepts to students. Without providing any direct answer, teacher had opened the floor for all. She had welcomed replies from students with a given time limit and searching opportunity to Fig. out the answer (Fig. 4). Within this time, students think and take the help of internet to seek the correct answer. The involvement of all students were possible in this step since there was no marks issue with wrong answer. The replies with mistakes made it more interesting to all to follow the lecture. Afterwards, the floor was open for discussion and the correct answer was formed with contribution from each participants (Fig. 5). 


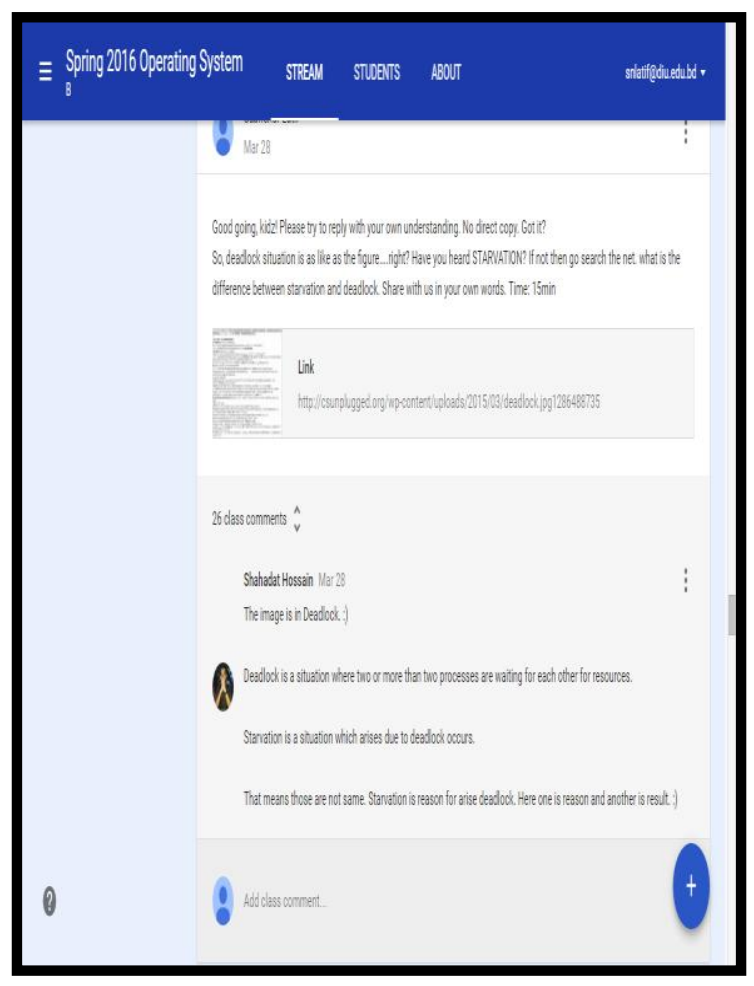

Fig. 4: Student is proactive in Live Class

\subsection{Test Case III for RQ 3: Do the students prefer Facebook groups as a platform for group study instead of Google classroom?}

Students are strongly connected with Facebook group. In the baseline survey it had been found that the students, who passed most of the times in Facebook, had poor CGPA. But sincere students who got good CGPA also depend on the Facebook group. Students like to discuss informal study preparation and collect learning materials from their own group instead of Google classroom (Fig. 7).To investigate the real situation, the writer got herself involved with a Facebook group of students. It was found that students solve study problems there by sharing and uploading image and other type of files. One gives the solution and other collects it (Fig. 6). Here they have a friendly environment to talk about anything without any restriction whereas Google classroom is the formal study place. They do not frequently check GC updates since they get almost everything in Facebook group. It has been tested by uploading a study material at the same time in GC as well as in Facebook group. All the active members have seen the post in Facebook group but in GC, not a single view of the post was found (Fig. 8).

In most of the times, GC is visited only when an assignment is due to submit. They rely on Facebook group for any notifications. Comparing to GC notices, Facebook group notices spread fast and response is also high. The teacher has tested it by taking a sudden class in Google classroom. She has shared this notice in Facebook group and most of them replied instantly (Fig. 9).

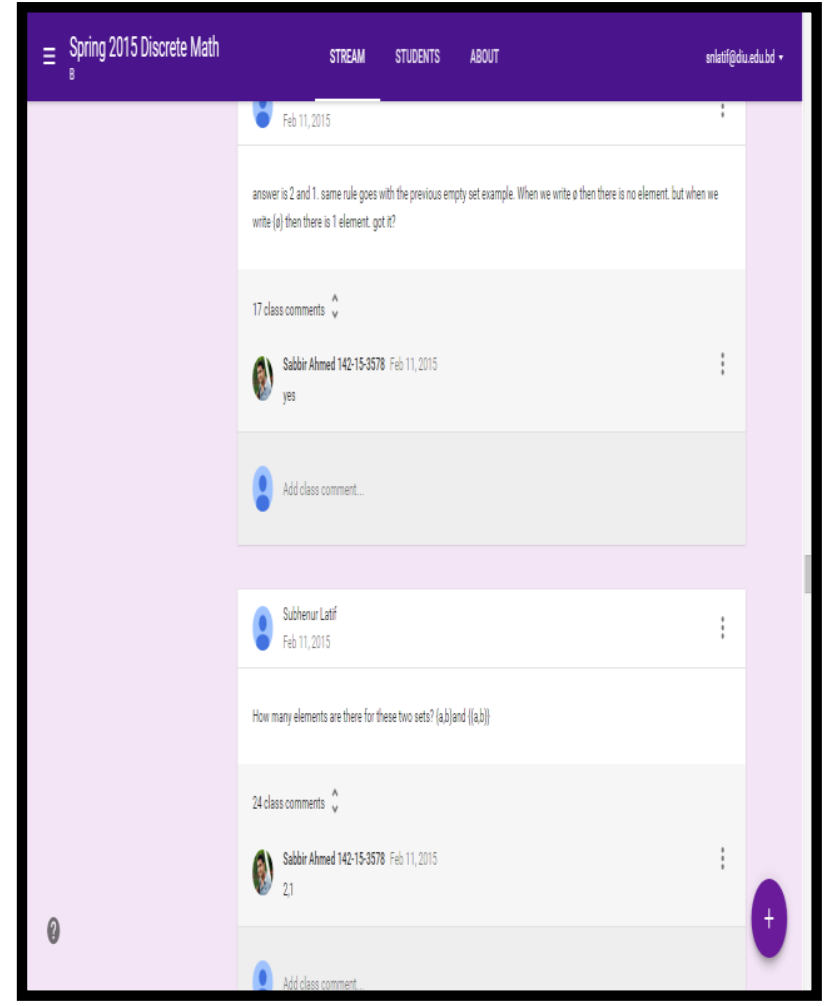

Fig. 5: Combined attempt in Live Class

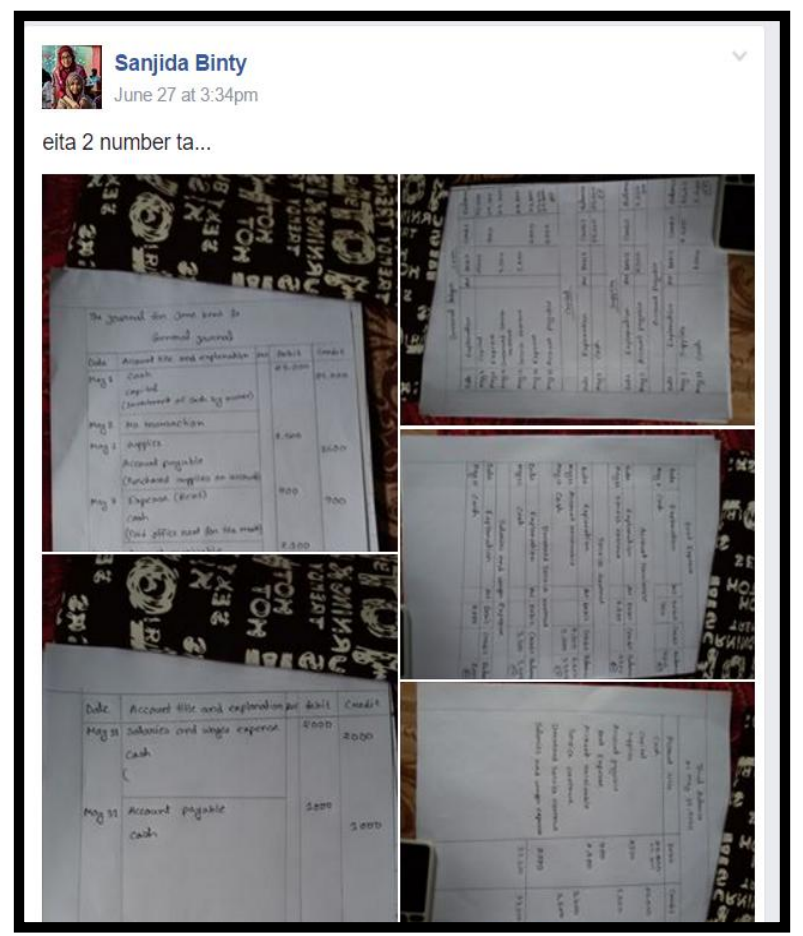

Fig. 6: Student is Sharing Solution in Facebook Group 


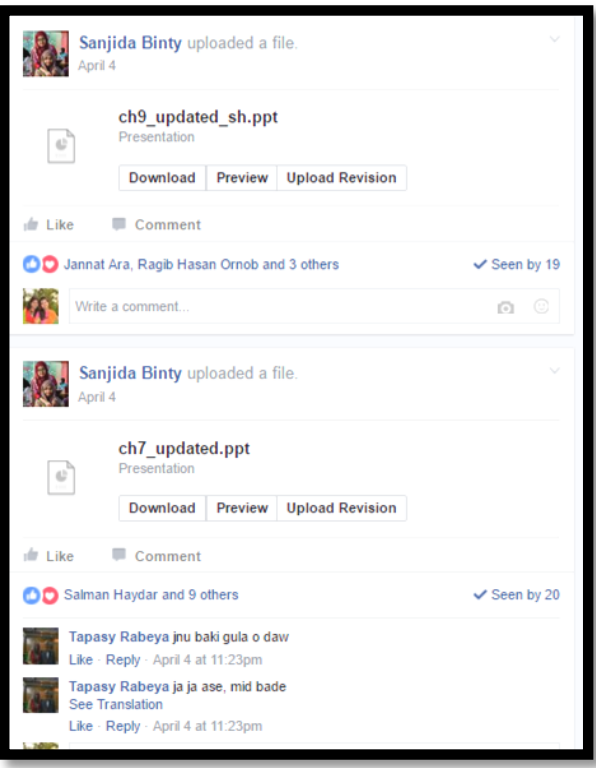

Fig. 7: Student is sharing Study Material In Facebook Group

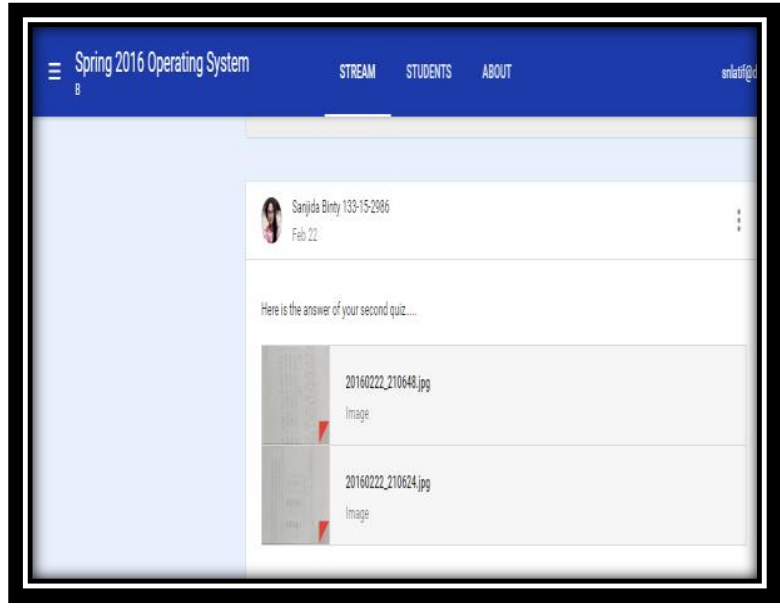

Fig. 8: Zero view of Study Material in Google Classroom

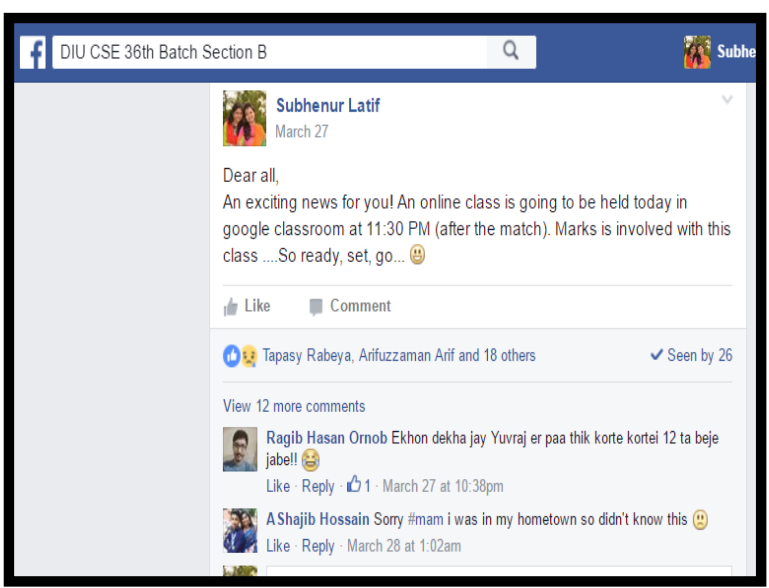

Fig. 9: Teacher is sharing notice in Facebook group where everybody is found active

\section{RESULTS and FINDINGS}

The Baseline Survey, Interviews and case studies had showed significant outcomes. These are discussed below:
Baseline Survey and Interview Findings:

i) Student profile showed that students bearing poor CGPA, spend more hours in Facebook (Table 1).

ii) The motivational factors for using Google classroom vary among different study levels (junior to senior) (Table 2).

Table 1. Student CGPA versus Facebooking Time

\begin{tabular}{|c|c|}
\hline $\begin{array}{c}\text { Time spent in Facebook } \\
\text { per week }\end{array}$ & Average CGPA \\
\hline Less than 7 hour & 3.83 \\
\hline 7-14 hours & 3.42 \\
\hline 14-20 hours & 3.25 \\
\hline More than 20 hours & 3.24 \\
\hline
\end{tabular}

Table 2. Variance in motivation factors for using Google classroom in different levels of study

\begin{tabular}{|c|c|c|c|}
\hline $\begin{array}{c}\text { Factor of } \\
\text { Motivation }\end{array}$ & Level 1 & Level 3 & Level 4 \\
\hline Marks & $\begin{array}{c}\text { All } \\
\text { agree }\end{array}$ & $\begin{array}{c}46 \% \\
\text { agree }\end{array}$ & $53 \%$ agree \\
\hline Solving Problems & $\begin{array}{c}\text { All } \\
\text { agree }\end{array}$ & $\begin{array}{c}46 \% \\
\text { agree }\end{array}$ & $65 \%$ agree \\
\hline Team Work & $\begin{array}{c}\text { All } \\
\text { agree }\end{array}$ & $\begin{array}{c}46 \% \\
\text { agree }\end{array}$ & $42 \%$ agree \\
\hline Peer Learning & $\begin{array}{c}98 \% \\
\text { agree }\end{array}$ & $\begin{array}{c}46 \% \\
\text { agree }\end{array}$ & $34 \%$ agree \\
\hline $\begin{array}{c}\text { Presence of a } \\
\text { Senior }\end{array}$ & $\begin{array}{c}92 \% \\
\text { agree }\end{array}$ & $\begin{array}{c}40 \% \\
\text { disagree }\end{array}$ & $\begin{array}{c}46 \% \\
\text { disagree }\end{array}$ \\
\hline Reward & $\begin{array}{c}99 \% \\
\text { agree }\end{array}$ & $\begin{array}{c}87 \% \\
\text { agree }\end{array}$ & $76 \%$ agree \\
\hline $\begin{array}{c}\text { Passive role of } \\
\text { Teacher }\end{array}$ & $\begin{array}{c}98 \% \\
\text { agree }\end{array}$ & $\begin{array}{c}65 \% \\
\text { agree }\end{array}$ & $53 \%$ agree \\
\hline
\end{tabular}

From these survey results, the research questions were formed for this study of student engagement with Google

\section{Classroom}

To find answer for each research question, case studies were adopted. The first research question was related with the association between peer influence and student engagement in critical thinking. The result showed that this peer teaching challenge motivated the students to give their best in order to get appreciation from peers. They have adopted creative ways to accomplish the task such as preparing the assignment in mother language to make it understandable to others, creating own video tutorial which is fascinating. A few of them who had copied directly from internet, could not answer the queries made by their peers and it was automatically revealed. Since the queries were related with marks, those were also interesting and thoughtful. It was clearly visible that students had to dig deeper in the knowledge field when he or she is about to explain it to others. Also, he or she had to reply the questions that their peers were asking and making queries through comments. Therefore, understanding, analyzing, creating, presenting and writing skills- all are happening in one task completion. So, it can be said that Google classroom can play an effective role for engaging students into critical 
thinking rather than following traditional ways of task assigning.

The second research question was regarding passive role of teacher in virtual classroom environment. Study showed, $100 \%$ class participation was ensured through the adopted strategy. Since the teacher had played the passive role, a good number of proactive participation was possible. The result of the case studies had been showed; students get a feeling of participation and are motivated to follow the remaining lecture. Instead of following the given answers blindfolded, students come forward with their own answer with the help of online resources. This leads to the ability of ownership and for the case of consideration, the result of research question is positive.

The test case study showed peer influence and passive role of teachers are significant determinants of learning engagement as well as effectiveness of Google classroom. Using the existing features of this app, teachers can design GC courses focusing on these two factors of motivation.

The third research question focuses on alternative platform (Facebook) as a reason of poor engagement in Google classroom. The writer herself investigated this matter and it came out that, at a great extent it is true for the sample case. In order to search for a solution, students were interviewed where they were asked to evaluate GC, their views as user and what they need in this tool. The summary is discussed below:

\subsection{Requirements and Suggestions from Level-1 Students}

Interview with level-1 students revealed to the elicitation of some requirements. They had evaluated Google classroom and shared their experience. In a nutshell, some specific points have found after analysis (Table 3). Some of these points are user requirements, some are problem that they are facing while using this tool and some are suggestions. Though they are very young yet they are well experienced in using technology which reflects good observations.

\subsection{Requirements and Suggestions from Level-3 Students}

Level-3 students are more mature comparing to level- 1 and 2 and that is why this level of study is chosen for interview. They have shared openly their experience with Google classroom and some significant feedbacks are mentioned in Table 4.

The feedbacks of students had shown less interest in Google classroom. The suggestions and demands from student perspective indicate that some extended features of this tool and innovative class design collectively might work to enhance interest in participating.

Table 3. Requirements and Suggestions from Level-1 Students

\begin{tabular}{|l|l|}
\hline 1. & Pop up desktop notification(Requirement) \\
\hline 2. & Private chat option(Requirement) \\
\hline 3. & $\begin{array}{l}\text { Google class room app is not user } \\
\text { friendly(Problem) }\end{array}$ \\
\hline 5. & Class room is not responsive (Problem) \\
\hline
\end{tabular}

6. Include Google hangout with Google classroom (Suggestion)

7. Post privacy option for students(Requirement)

8. Marks should be counted for performance of the classroom (Suggestion)

9. User interface is not attractive (Problem)

10. After finishing one topic teacher should give some important related questions and take an online class test (Suggestion)

11. Rating System for student class room performance(Suggestion)

12. Access option to see other group member profile as like as Facebook (Suggestion)

Table 4. Requirements and Suggestions from Level-3 Students

\begin{tabular}{|c|l|}
\hline 1. & Passive role of teacher (Requirement) \\
\hline 2. & Blocking facility(Requirement) \\
\hline 3. & Opportunity to edit a post(Requirement) \\
\hline 4. & Problems with uploaded files (Problem) \\
\hline 5. & Group chat(Requirement) \\
\hline 7. & $\begin{array}{l}\text { Voice/Video Calling, live chat, like option, } \\
\text { emoticons(Requirement) }\end{array}$ \\
\hline 8. & $\begin{array}{l}\text { Before mid and final exams, a live class with } \\
\text { teacher for problem solving and } \\
\text { review(Requirement) }\end{array}$ \\
\hline 9. & $\begin{array}{l}\text { Visualization of user status(Active/ inactive) } \\
\text { (Requirement) }\end{array}$ \\
\hline 10. & $\begin{array}{l}\text { Marks should be awarded for Google class } \\
\text { performance (Suggestion) }\end{array}$ \\
\hline
\end{tabular}

\section{LIMITATIONS of the STUDY}

Sample size was small for case studies and analysis of the data was limited to only computer Science and Engineering students- these are some limitations of the study.

\section{CONCLUSION}

This study focuses on finding the main factors for students' poor engagement in Google classroom. The research continued considering some research questions and the answers are found from case studies and student feedbacks.

\section{REFERENCES}

[1] Bosch, Using online social networking for teaching and learning: Facebook use at the University of Cape Town, South African Journal for Communication Theory and Research, Volume 35, Issue 2, 2009

[2] Chou and Pi, The Effectiveness of Facebook Groups for e-Learning, International Journal of Information and Education Technology, Vol. 5, No. 7, July 2015 
[3] Heu, Students' and teachers' use of Facebook, Computers in Human Behavior, Volume 27, Issue 2, March 2011, Pages 662-676

[4] Cheung, Chiu, Lee, Online social networks: Why do students use Facebook? Computers in Human Behavior, Volume 27, Issue 4, July 2011, Pages 1337-1343

[5] Yu, Tian, Vogel, Kwok, Can learning be virtually boosted? An investigation of online social networking impacts, Volume 55, Issue 4, December 2010, Pages 1494-1503

[6] Albyrak, Yildirim, Using Social Networking Sites for Teaching and Learning Students' Involvement in and Acceptance of Facebook as a Course Management System, Journal of Educational Computing Research, April 2015 52: 155-179, first published on March 26, 2015
[7] Chehayeb, A. (2015). New in Classroom: saving time while grading. Retrieved from Googleforeducation.blogspot.com/2015/12/new-in-Classroom-saving-tim

[8] Martin, F and Parker, M. A., Use of Synchronous Virtual Classrooms: Why, Who, and How? MERLOT Journal of Online Learning and Teaching Vol. 10, No. 2, June 2014 p 192-210

[9] Keeler, A. "15 More things you can do with Google Classroom". Retrieved from http://www.alicekeeler.com/teachertech/2014/09/22/15more-things-you-can-do-with-Google-classroom/

[10] Janzen, M. (2014) "Hot Team : Google Classroom". Retrieved from tlt.psu.edu/2014/12/04/hot-team-Googleclassroom

[11] Wiersma, W., \& Jurs, S.G. (2005). Research Methods in Education: An Introduction. Boston: Pearson. 